\title{
MENUMBUHKEMBANGKAN MINAT BACA MENUJU MASYARAKAT LITERAT
}

\author{
Sri Wahyuni \\ Jurusan Pendidikan Bahasa dan Sastra Indonesia \\ FKIP Universitas Islam Malang \\ Email: sriwy@yahoo.co.id
}

\begin{abstract}
Research findings show that in general Indonesian students' reading ability is still low. This is attributable to, among others, poor reading habit, which is caused by low reading motivation. Several aspects cause low reading motivation: (1) family and neighborhood environments that do not support reading habit, (2) society's low bookbuying power, (3) limited number of good libraries, (4) negative effects of electronic media development, (5) learning model that in general does not make students read, and (6) inappropriate learning system for reading. To improve reading motivation several attempts can be made: (1) making children get used to reading since their early age, (2) providing interesting books, (3) creating an environment conducive for reading, (4) reconstructing the library performance to make it interesting, and (5) developing a learning model for reading that is enjoyable, varied, and educative.
\end{abstract}

Keywords: reading motivation, literate society

\section{A. PENDAHULUAN}

Minat baca masyarakat Indonesia termasuk siswa-siswi kita masih rendah. Masyarakat kita lebih senang budaya lisan atau tutur. Kita belum menjadi society book reader. Kondisi ini berbeda dengan negara-negara di sekitar kita yang telah menjadikan membaca sebagai aktivitas rutin setiap hari. Kondisi ini tentu memicu rendahnya kemampuan membaca masyarakat kita.

Sekolah yang termasuk ke dalam masyarakat ilmiah, seharusnya didesain untuk menumbuhkembangkan kegemaran membaca. Siswa sebagai kaum terpelajar dituntut untuk selalu mengikuti perkembangan informasi terkini. Oleh karena itu, sangat dibutuhkan pembiasaan membaca yang memadai. Akan tetapi, kenyataannya tidak demikian. Dalam sebuah penelitian terungkap bahwa kebanyakan siswa lebih mementingkan membeli pulsa HP daripada membeli buku. Banyak ditemui, siswa lebih suka menikmati kegiatan berkomunikasi dengan HP daripada membaca dan menambah koleksi bukunya.
Banyak bukti lagi yang menunjukkan bahwa di kalangan siswa belum terbentuk budaya atau kegemaran membaca. Banyak siswa yang hanya membaca atau mencari buku jika ada tugas dari guru. Tidak banyak siswa yang secara sadar dan mandiri melakukan kegiatan membaca untuk memperluas pengetahuan mereka. Ini menunjukkan betapa masih rendahnya minat baca mereka.

Belum terbentuknya kebiasaan atau kegemaran membaca di kalangan siswa, diduga tentu ini berimplikasi pada kemampuan mereka dalam membaca. Kemampuan membaca merupakan saah satu ciri masyarakat literat. Secara sederhana, masyarakat literat adalah masyarakat yang memiliki kemampuan membaca dan menulis atau melek aksara. Hal ini sejalan dengan pendapat Grabe \& Kaplan (1992) dan Graff (2006) yang mengartikan literacy sebagai mampu untuk membaca dan menulis (able to read and write), sedangkan orang yang mampu keduanya disebut literat.

Kemampuan membaca merupakan kemampuan dasar dalam belajar karena hampir 
semua kemampuan untuk memperoleh informasi dalam belajar bergantung pada kemampuan tersebut. Melalui membaca, seseorang dapat menggali informasi, mempelajari pengetahuan, memperkaya pengalaman, mengembangkan wawasan, dan mempelajari segala sesuatu. Oleh karena itu, rendahnya minat baca dan rendahnya kemampuan membaca oleh para generasi muda akan berdampak buruk terhadap pengembangan diri dan kinerja mereka yang selanjutnya akan berdampak buruk terhadap pembangunan bangsa. Sejarah belum mencatat ada orang pintar dan hebat yang tidak banyak membaca. Berkaitan dengan ulasan tersebut, berikut ini akan dikaji secara khusus tentang 1) gambaran kemampuan membaca siswa Indonesia, (2) penyebab rendahnya minat dan kemampuan membaca siswa, (3) solusi menumbuhkembangkan minat dan kemampuan membaca siswa.

\section{B. GAMBARA N KEMAMPUAN MEMBACASISWA INDONESIA}

Rendahnya minat baca masyarakat termasuk siswa-siswi kita menjadikan kebiasaan membaca yang rendah, dan kebiasaan membaca yang rendah ini menjadikan kemampuan membaca rendah. Rendahnya kemampuan membaca siswa-siswi kita antara lain tergambar dalam hasil riset berikut ini.

Laporan Bank Dunia No. 16369-IND, dan Studi IEA (International Association for the Evalution of Education Achievermen) di Asia Timur, menunjukkan bahwa tingkat terendah membaca anak-anak dipegang oleh negara Indonesia. Kajian PIRLS (Progress in International Reading Literacy Study) yaitu studi internasional dalam bidang membaca pada anak-anak di seluruh dunia yang disponsori oleh IEA ini menunjukkan bahwa rata-rata anak Indonesia berada pada urutan keempat dari bawah dari 45 negara di dunia. Kajian PIRLS ini menempatkan siswa Indonesia kelas IV Sekolah Dasar pada tingkat terendah di kawasan Asia. Indonesia mendapat skor 51.7, di bawah Filipina (skor 52.6);
Thailand (skor 65.1); Singapura (74.0); dan Hongkong (75.5). Bukan itu saja, kemampuan anak-anak Indonesia dalam menguasai bahan bacaan juga rendah, yaitu 30 persen saja dari materi bacaan karena mereka mengalami kesulitan dalam menjawab soal-soal bacaan yang memerlukan pemahaman dan penalaran.

Studi internasional mengenai literasi membaca yang dilakukan OECD (Organization for Economic Co-operation Development) bisa dijadikan cermin peta kemampuan literasi siswa Indonesia dibandingkan siswa lain seusia mereka di tataran internasional. OECD sendiri mencoba memetakan profil literasi membaca siswa dalam ruang lingkup internasional melalui kajian PISA (Programme for International Student Assessment). PISA adalah studi literasi yang bertujuan untuk meneliti secara berkala tentang kemampuan siswa usia 15 tahun (kelas III SMP dan kelas I SMA) dalam membaca (reading literacy), matematika (mathematics literacy), dan sains (scientific literacy). Studi PISA melaporkan bahwa 25\% - 34\% dari siswa Indonesia masuk dalam tingkat literasi-1. Artinya, sebagian besar siswa kita masih memiliki kemampuan membaca pada taraf 'belajar membaca'. Siswa pada tingkat literasi-1 hanya mampu untuk membaca teks yang paling sederhana, seperti menemukan informasi yang ada di dalam bacaan sederhana, mengidentifikasi tema utama suatu teks atau menghubungkan informasi sederhana dengan pengetahuan sehari-hari. Sedangkan untuk taraf tingkat literasi-5, kurang dari 1\% siswa Indonesia berada pada taraf tertinggi dari studi PISA ini. Artinya, hanya sedikit dari siswa kita memiliki kemampuan membaca yang canggih, seperti menemukan informasi yang rumit dalam teks yang tidak dikenal sebelumnya, mempertunjukkan pemahaman yang terperinci, menarik kesimpulan dari informasi yang ada di dalam teks, dan mengevaluasi dengan kritis, membangun hipotesis, serta mengemukakan konsep yang mungkin bertentangan dengan harapannya sendiri.

Data lain juga menyebutkan hal yang sama. Pada dokumen UNDP dalam Human 
Development Report 2000 melaporkanh bahwa angka melek huruf orang dewasa di Indonesia hanya 65,5 persen, sedangkan Malaysia sudah mencapai 86,4 persen, dan negara-negara maju seperti Australia, Jepang, Inggris, Jerman, dan Amerika Serikat umumnya sudah mencapai 99,0 persen. Dengan kondisi seperti itu, tidak heran bila kualitas pendidikan di Indonesia juga buruk. Dalam hal pendidikan, survei The Political and Economic Risk Country (PERC), sebuah lembaga konsultan di Singapura, pada akhir 2001, menempatkan Indonesia di urutan ke-12 dari 12 negara di Asia yang diteliti.

Hasil survey lembaga underbouw Perserikatan Bangsa-bangsa (PBB), UNESCO (United Nation Education Society and Cultural Organization), juga menemukan fakta: minat baca masyarakat Indonesia betul-betul rendah, bahkan paling rendah di Asia. Berdasarkan data tersebut, diketahui bahwa minat baca masyarakat Indonesia khususnya di kawasan Asia Tenggara saja menduduki peringkat keempat, setelah Malaysia, Thailand, dan Singapura (http://www.cybermq.com).

Bukti-bukti di atas menunjukkan bahwa minat baca di kalangan masyarakat termasuk siswa-siswi kita memang masih rendah. Apakah budaya membaca, sebagai wujud komitmen terhadap proses pendidikan sudah sedemikian dipandang tidak penting oleh sebagian besar masyarakat kita? Padahal, minat membaca yang tinggi sangat penting. Kesuksesan pendidikan anak sangat bergantung pada kemampuan membaca. Minat baca yang rendah mempengaruhi kemampuan anak dan secara tidak langsung berakibat pada rendahnya daya saing mereka dalam percaturan nasional dan internasional. Sejarah belum mencatat ada orang pintar dan hebat yang tidak banyak membaca.

Pertanyaannya sekarang adalah mengapa sampai terjadi demikian? Berikuti ini hasil suatu analisis mengapa minat dan kemampuan membaca masyarakat khususnya siswa-siswi kita rendah.

\section{PENYEBAB RENDAHNYA MINAT DAN KEMAMPUAN MEMBACA SISWA}

Rendahnya kemampuan membaca masyarakat yang tergambar dalam riset-riset seperti yang telah dijelaskan di atas disebabkan oleh rendahnya kebiasaan membaca, dan rendahnya kebiasaan membaca disebabkan oleh rendahnya minat baca masyarakat. Banyak aspek yang menyebabkan rendahnya minat baca masyarakat.

Pertama, penyebab rendahnya minat baca adalah lingkungan keluarga dan sekitar yang kurang mendukung kebiasaan membaca. Kesibukan orangtua dalam berbagai kegiatan sehingga setiap hari waktu luang sangat minim bahkan hampir tidak ada untuk melakukan kegiatan membaca. Anak yang setiap hari jarang melihat keluarganya melakukan kegiatan membaca secara umum juga kurang memiliki kegemaran membaca. Demikian juga lingkungan sekitar seperti masyarakat sekitar yang kurang mendukung kebiasaan membaca juga akan mempengaruhi minat baca yang rendah.

Kedua, rendahnya minat baca disebabkan oleh rendahnya daya beli buku masyarakat berkaitan dengan rendahnya tingkat ekonomi dan rendahnya kesadaran pentingnya buku. Tuntutan hidup di zaman sekarang ini cukup tinggi. Harga-harga kebutuhan hidup melambung tinggi. Secara umum penghasilan masyarakat telah habis untuk memenuhi kebutuhan konsumsi hidup sehari-hari. Apalagi untuk membeli buku anakanaknya, untuk mencukupi kehidupan seharihari pun terkadang masih kurang. Kondisi ini menjadikan masyarakat termasuk siswa-siswi dari lingkungan keluarga tersebut kurang akrab dan merasa asing dengan buku dan akhirnya memiliki minat membaca yang rendah. Rendahnya daya beli buku masyarakat tersebut ternyata tidak hanya disebabkan alasan ekonomi, tetapi juga disebabkan oleh faktor rendahnya kesadaran pentingnya buku dalam kehidupan. Pada golongan ekonomi masyarakat menengah atau pun atas ternyata 
tidak menjamin daya beli buku mereka juga tinggi.

Ketiga, rendahnya minat baca masyarakat termasuk siswa-siswi kita disebabkan oleh minimnya jumlah perpustakaan yang kondisinya memadai. Menurut data Deputi Pengembangan Perpustakaan Nasional RI (PNRI) dari sekitar 300.000 SD sampai SLTA, baru 5\% yang memiliki perpustakaan layak. Bahkan, diduga hanya $1 \%$ dari $260.000 \mathrm{SD}$ yang mempunyai perpustakaan. Selain itu, diketahui juga baru sekitar 20\% dari 66.000 desa/kelurahan yang memiliki perpustakaan memadai (Kompas, 25/7/02). Banyak ruang perpustakaan 'sumpek' sehingga kurang menarik untuk dikunjungi. Koleksi buku yang tidak lengkap, buku-buku yang sudah 'kadaluwarsa', sarana yang kurang mendukung, akan menyebabkan orang malas ke perpustakaan. Untuk perpustakaan sekolah, buku-buku yang tersedia umumnya buku-buku teks, buku-buku paket, atau buku-buku pelajaran yang didrop dari pusat. Pada akhirnya, perpustakaan sebagai jantung sekolah jarang dimanfaatkan siswa sebab koleksi bukubuku tidak mengalami perubahan. Jarang sekali perpustakaan sekolah menyediakan buku-buku umum yang memperluas pengetahuan siswa, buku-buku pelajaran penunjang yang bermutu, buku-buku agama bermutu tempat siswa belajar seluk-beluk agama, atau buku-buku bacaan sejenis karya sastra baik yang lama maupun baru. Karya sastra seperti novel, cerpen, dan jenis prosa lainnya sebenarnya merupakan salah satu media yang tepat untuk membangkitkan minat baca. Cerita dalam karya sastra mengisahkan tokoh-tokoh dalam dunia fiksi yang tidak lepas begitu saja dengan dunia fakta. Karya sastra mengandung pesan moral, mengembangkan imajinasi dan menawarkan pengalaman baru bagi pembacanya. Sastra adalah satu dunia yang menawarkan keutuhan yang dapat mengerakkan jiwa dan rasa, yang dapat mengubah manusia menjadi lebih halus dan peka. Setiap karya dalam sastra itu, menawarkan satu moral. Moral itu terjalin menjadi jiwa cerita, menjadi nafas, ucapan dan perilaku para tokohnya. Itulah sebabnya, buku yang bernilai sastra selalu dapat memberikan ajaran yang baik yang dapat memperkaya batin manusia.

Keempat, penyebab rendahnya minat baca adalah dampak negatif perkembangan media elektronik. Acara televisi dan radio sekarang ini dibuat sedemikian menarik dan beragam sehingga masyarakat dari berbagai latar belakang dan usia dimanjakan oleh acaraacara yang mereka tonton/dengar. Hal ini didukung oleh data yang dikeluarkan Badan Pusat Statistik (BPS) pada 2006 yang menunjukkan, bahwa masyarakat kita belum menjadikan kegiatan membaca sebagai sumber utama mendapatkan informasi. Orang lebih memilih menonton TV $(85,9 \%)$ dan/atau mendengarkan radio $(40,3 \%)$ daripada membaca koran $(23,5 \%)$ (www.bps.go.id). Selain itu, banyaknya jenis hiburan seperti permainan (game) elektronik, surfing di internet, dan lain-lain mampu mengalihkan perhatian anak-anak dan orang dewasa dari buku. Internet sebenarnya masih dapat dimasukkan sebagai kegiatan membaca. Tetapi yang dapat dilihat di internet bukan hanya tulisan tetapi hal-hal visual lainnya yang kadangkala kurang tepat bagi konsumsi anakanak.

Kelima, penyebab rendahnya minat membaca siswa Indonesia adalah karena model pembelajaran secara umum belum membuat siswa harus membaca. Tidak banyak model pembelajaran yang menugaskan siswa untuk membaca buku, mencari informasi/ pengetahuan lebih dari apa yang diajarkan dari berbagai sumber, mengapresiasi karya-karya ilmiah seperti artikel, karya-karya sastra, dan sebagainya. Pembelajaran di sekolah masih mengandalkan pada kehadiran guru dengan ceramahnya setiap hari. Pembelajaran seperti ini menjadikan siswa sebagai pendengarpendengar tanpa daya, yang hanya mengkonsumsi informasi yang kurang 'bermakna'. Informasi/pengetahuan yang diperoleh sendiri oleh siswa sendiri biasanya lebih melekat, lebih banyak, dan lebih bermakna bagi dirinya. Hal ini dapat dicapai apabila siswa diberi kesempatan untuk mencari 
dan menemukan sendiri informasi/pengetahuan itu antara lain lewat membaca buku dan media lain yang ditugaskan.

Keenam, penyebab rendahnya minat dan kemampuan membaca siswa adalah karena sistem pembelajaran membaca yang belum tepat. Dalam Kompas 29 Oktober 2009 disebutkan, "Kemampuan membaca siswa sekolah di tingkat sekolah dasar/madrasah ibtidaiyah (SD/MI) saat ini memiliki kecenderungan rendah. Lemahnya kemampuan membaca siswa SD/MI patut diduga karena lemahnya pembelajaran Bahasa Indonesia, khususnya pembelajaran membaca". Hasil laporan penelitian "Studi Penilaian Kemampuan Guru Melalui Video dengan Memanfaatkan Data PIRLS" oleh Prof Dr Suhardjono dari Pusat Penelitian Pendidikan Depdiknas di Jakarta menunjukkan, muara dari lemahnya pembelajaran membaca patut diduga karena kemampuan guru dalam mengajar dan kondisi sekolah. Kondisi sekolah yang dimaksud meliputi sarana dan prasarana, jumlah siswa dalam kelas, akses ke sekolah, dan prestasi sekolah.

\section{SOLUSI MENGATASI RENDAHNYA MINAT DAN KEMAMPUAN MEMBACA}

Bagaimanakah upaya membangkitkan minat baca masyarakat agar menjadi masyarakat yang literat? Sebenarnya telah banyak kajian tentang bagaimana membangkitkan minat baca. Beberapa hal berikut ini dapat dilakukan sesuai dengan proporsi tugas dan peran kita masing-masing.

\section{Membiasakan Anak Membaca Sejak Dini}

Pertumbuhan minat baca bisa dimulai sejak bayi lahir. pada masa 0-2 tahun perkembangan otak anak amat pesat $(80 \%$ kapasitas otak manusia dibentuk pada periode dua tahun pertama) dan amat reseptif (gampang menyerap apa saja dengan memori yang kuat). Bila sejak usia 0-2 tahun sudah dikenalkan dengan membaca, kelak mereka akan memiliki minat baca yang tinggi. Oleh karena itu dalam usia dini anak perlu dikenalkan dengan dunia membaca. Otak mereka akan merekam isi bacaan apa pun yang disampaikan orang tuanya dengan berbagai gaya cerita.

Banyaknya keluarga di Indonesia yang belum mentradisikan kegiatan membaca pada anak-anaknya. Padahal, jika ingin menciptakan anak-anak yang memiliki pikiran luas dan baik akhlaknya, mau tidak mau kegiatan membaca perlu ditanamkan sejak dini.

Keterampilan membaca merupakan salah satu modal utama bagi anak. Dengan bekal kemampuan membaca, anak dapat mempelajari sesuatu yang diinginkannya. Kegagalan dalam penguasaan keterampilan ini akan mengakibatkan masalah yang fatal, baik untuk melanjutkan pendidikan ke jenjang yang lebih tinggi, maupun untuk menjalani kehidupan sosial kemasyarakatan nantinya.

\section{Menyediakan Buku yang Menarik}

Upaya merangsang masyarakat untuk mau membaca dapat dilkukan dengan penyediaan bahan-bahan bacaan yang menarik, sesuai dengan kebutuhan dan kepentingan masing-masing kelompok umur. Dengan kata lain, ketersediaan bahan bacaan memungkinkan tiap orang untuk memilih apa yang sesuai dengan minat dan kepentingannya. Dari situlah, tumbuh harapan bahwa masyarakat kita akan semakin mencintai bahan bacaan. Implikasinya, taraf masyarakat akan kian meningkat.

Upaya ini terkadang terbentur dengan masih rendahnya penyediaan buku baik oleh pemerintah maupun swasta. Jumlah penerbitan buku di Indonesia masih timpang dibandingkan dengan jumlah penduduk. Dalam setahun, penerbitan buku di seluruh dunia mencapai satu juta judul buku. Tetapi untuk Indonesia, paling tinggi hanya mampu mencapai lima ribuan judul. Berdasarkan data dari Intenational Publisher Association Kanada, produksi perbukuan paling tinggi ditunjukkan oleh Inggris, yaitu mencapai rata-rata 100 ribu judul buku per tahun. Tahun 2000 saja sebanyak 110.155 judul buku. Posisi kedua ditempati 
Jerman dengan jumlah judul buku yang diterbitkan pada tahun 2000 mencapai 80.779 judul, Jepang sebanyak 65.430 judul buku. Sementara itu, Amerika Serikat menempati urutan keempat. Indonesia pada tahun 1997 pernah menghasilkan lima ribuan judul buku. Tetapi, tahun 2002 tercatat hanya 2.700-an judul. Sangat jauh apabila dibandingkan dengan produksi penerbitan buku tingkat dunia. Bila dibandingkan dengan tetangga kita, Malaysia, dalam hal minat baca dan oplah buku, kita sangat jauh tertinggal. Data statistik menyebutkan, dalam 10 tahun terakhir Indonesia baru menerbitkan 2500 judul buku per tahun. Sementara, di Malaysia yang berpenduduk sepersepuluh dari negara kita sudah memproduksi 9.600 judul buku per tahun.

Lepas dari kondisi ketersediaan buku yang ada di Indonesia, setiap lembaga mestinya ada upaya untuk menyediakan buku-buku dan bahan bacaan lain yang menarik. Khusus untuk anak-anak, agar tumbuh minat baca diperlukan buku-buku yang bersifat menghibur dan sekaligus mendidik. Pada anak perlu diberikan buku-buku yang penuh warna-warni dan isinya memikat daya fantasi. Di samping untuk mengenalkan bentuk, juga mengenalkan warna pada anak. Dengan pengenalan buku pada anak sejak dini, maka minat baca pada anak akan tumbuh. Sesuai dengan prinsip psikologi bahwa cara bertindak seseorang akan sangat dipengaruhi oleh kebiasaan yang terekam dalam memori otaknya semasa kecil. Belum cukup itu saja, sesuai dengan tahap psikologisnya, anak-anak umumnya lebih menyukai buku cerita. Buku cerita komik misalnya, ini merupakan bacaan populer untuk anak-anak. Anak-anak sangat menggandrungi cerita dalam bentuk komik tersebut, apalagi sebagian cerita tersebut pernah ditayangkan di televisi berupa film kartun seperti Doraemon, Ninja Hatori, Sinchan, Dragon Ball dan lainlain. Walaupun cerita berbau asing, akan tetapi hal itu ternyata sudah sangat membantu dalam gerakan minat baca. Cerita-cerita rakyat asli Indonesia sudah juga mulai digemari karena kemasan bukunya yang menarik. Nah sekarang, mengapa buku-buku pelajaran tidak ditulis saja dalam bentuk komik misalnya? Dengan bentuk bacaan seperti itu, buku-buku itu akan menarik bagi anak untuk dibaca.

Khusus untuk remaja, agar tumbuh minat baca diperlukan buku-buku yang menghibur seperti jenis bacaan sastra, juga koleksi mengikuti buku-buku baru yang mengikuti selera zaman. Kalaupun bentuknya dongeng yang merupakan cerita lama, tetapi kemasan buku tersebut harus ditampilkan dengan menarik serta dicetak dengan kertas yang bagus dan ilustrasi yang indah. Masih ingat buku Harry Potter karya J.K Rowling yang menghebohkan itu? Ketika buku edisi ketujuh misalnya diluncurkan, di Inggris para remaja telah berderet antrian panjang di depan toko buku yang akan menjualnya. Hal serupa juga terjadi di Amerika, panjang antrian di depan toko buku sampai mencapai lima ribuan orang. Dalam satu hari saja, buku itu telah terjual sekitar lima juta kopi. Dan, tidak dapat dibayangkan berapa angka penjualan selanjutnya, jika buku itu telah tersebar ke berbagai negara dan diterjemahkan pula. Ada pelajaran yang dapat kita petik ketika mengikuti berita "heboh" peluncuran buku Harry Potter. Yang perlu kita kagumi sebenarnya adalah minat baca dari anak-anak Inggris dan Amerika yang sangat tinggi. Pantaslah anak-anak di negara maju pendidikannya tinggi dan cerdascerdas, karena tingkat bacaan dan ingin tahu mereka cukup tinggi. Budaya membaca inilah yang belum ada pada diri anak-anak Indonesia. Inilah salah satu penyebab mengapa negara kita masih terbelakang dari beberapa aspek. Bagaimanapun, membaca adalah gerbang ilmu pengetahuan dan kearifan. Ini tantangan bagi penyedia buku bagaimana menyediakan buku yang mampu menyedot banyak orang untuk mau membacanya.

\section{Menciptakan Lingkungan yang Mendukung Kebiasaan Membaca}

Rendahnya daya beli buku dan minat baca kadang-kadang berkaitan erat dengan budaya bukan melulu soal ekonomi. Jadi, cara menyelesaikannya juga dengan pendekatan 
budaya. Karena ini mengubah budaya, maka tidak bisa terjadi dengan cepat. Meski perubahan lambat, namun harus tetap diusahakan terus demi memperoleh kebiasaan sepanjang hayat. Salah satu cara menciptakan lingkungan tersebut adalah kebiasaan membaca dalam keluarga dan lingkungan sekitar. Keluarga sangat dominan dalam perkembangan literasi anak. Hasil riset menunjukkan bahwa umumnya anak mulai belajar membaca dari orang tua di rumah. Mereka akan gemar membaca jika melihat orang tua atau anggota keluarga lain di rumah sering membaca buku, koran, atau majalah. Saatnya kini kita mulai melangkah nyata dalam meningkatkan minat baca terutama pada anak-anak. Anak-anak pada hakikatnya akan meniru apa yang mereka lihat di sekelilingnya. Untuk meningkatkan minat baca, memang seharunya dimulai dari usia sangat dini karena minat ini tumbuh sebagai hasil kebiasaan membaca. Orang tua yang mampu harus dipacu untuk memiliki perpustakaan pribadi sehingga memotivasi anak untuk membaca. Hal ini sekaligus menjadi alternatif yang baik untuk mengurangi jam menonton TV.

Lingkungan sekitar juga sangat berpengaruh pada peningkatan minat baca seseorang. Orang yang tinggal di lingkungan masyarakat yang di situ orang-orangnya gemar membaca, maka akan mempengaruhi orang tersebut untuk gemar membaca pula. Untuk membenahi minat baca masyarakat yang rendah, kita perlu mencontoh negara-negara maju yang masyarakatnya sudah menganggap bacaan sebagai kebutuhan primer. Misalnya masyarakat Jepang, yang dikenal mempunyai prinsip sebaik-baiknya teman duduk adalah buku. Di Jepang, masyarakat begitu akrab dengan bacaan. Di bank-bank, halte bus atau kereta, di lobi-lobi hotel, orang-orang Jepang terbiasa mengisi waktu dengan membaca. Kebiasaan ini pula yang membuat Jepang mampu menjadi negara industri besar. Ini perlu kita contoh dalam membiasakan membaca, yang tidak harus mengacu pada salah satu tempat misalnya perpustakaan.

\section{Memperbaiki Kembali Penampilan Perpustakaan agar Menarik}

Apabila yang menjadi alasan adalah rendahnya daya beli buku, maka dengan adanya perpustakaan yang nyaman, fasilitas yang memadai, serta pustaka yang relatif lengkap dan baru akan membuat kita menjadi gemar membaca. Meskipun hampir semua sekolah sudah memiliki perpustakaan (apa pun bentuknya), tidak semuanya memiliki koleksi buku yang memadai atau dikelola dan dimanfaatkan secara profesional. Dengan meningkatkan layanan dan fasilitas di perpustakaan, maka diharapkan minat baca masyarakat menjadi meningkat. Dengan cara ini, upaya meningkatkan minat baca akan sangat terbantu. Pada gilirannya, secara ekonomis sangat meringankan orangtua yang tidak harus perlu membeli buku sendiri untuk anak-anaknya. Selain itu di tiap kota perlu ada perpustakaan umum yang terbuka untuk seluruh penduduk kota itu. Orang-orang yang ingin menambah informasi/pengetahuan akan tertolong oleh perpustakaan. Mereka tidak perlu mengeluarkan beaya karena buku-buku yang diperlukan telah tersedia di perpustakaan umum. Dengan tersedianya buku bagi tiap dan semua orang, menjadikan masyarakat makin cerdas dan kreatif. Mereka akan membuka usaha, berani mandiri, bekerja secara profesional, mampu bersaing, berdiri tegak di antara bangsa-bangsa.

\section{Mengembangkan Model Pembelajaran Membaca yang Menyenangkan, Bervariasi, dan Mendidik}

Sistem pendidikan perlu direformasi agar mampu mengembangkan kemampuan membaca siswa. Pembelajaran di sekolah harus lebih diarahkan pada pengembangan kreativitas dan daya berpikir kritis mereka. Siswa harus dibiasakan dengan tugas membaca dan membuat jurnal atau laporan bacaan. Dengan jurnal mereka memiliki kebebasan untuk mengekspresikan pendapat tentang buku yang mereka baca. Hal ini akan meningkatkan daya nalar dan kritis siswa yang merupakan awal lahirnya generasi yang literat. 
Model pembelajaran sebaiknya lebih banyak diarahkan pada kegiatan membaca buku atau sumber lain untuk mencari lebih banyak informasi/pengetahuan tentang apa yang diajarkan. Bila ini dilakukan dengan benar, kegemaran membaca akan terbentuk dan daya kritis siswa bisa timbul.

Berikut ini beberapa model pembelajaran membaca yang dapat digunakan guru agar pembelajaran membaca menjadi suatu kegiatan yang menyenangkan bagi peserta didik sehingga pada akhirnya dapat menumbuhkembangkan kegemaran atau motivasi mereka untuk membaca.

\section{Model Pembelajaran Membaca untuk Kelas Awal (Permulaan)}

Membaca permulaan dalam pengertian ini adalah membaca permulaan dalam teori ketrampilan, maksudnya menekankan pada proses penyandian membaca secara mekanikal. Membaca permulaan yang menjadi acuan adalah membaca merupakan proses recoding dan decoding. Melalui proses recoding, pembaca mengasosiasikan gambargambar bunyi beserta kombinasinya itu dengan bunyibunyinya. Dengan proses tersebut, rangkaian tulisan yang dibacanya menjelma menjadi rangkaian bunyi bahasa dalam kombinasi kata, kelompok kata, dan kalimat yang bermakna. Di samping itu, pembaca mengamati tanda-tanda baca untuk mrmbantu memahami maksud baris-baris tulisan. Melalui proses decoding, gambar-gambar bunyi dan kombinasinya diidentifikasi, diuraikan kemudian diberi makna. Proses ini melibatkan knowledge of the world dalam skemata yang berupa kategorisasi sejumlah pengetahuan dan pengalaman yang tersimpan dalam gudang ingatan (Syafi'ie, 1999: 7).

Pada tingkatan membaca permulaan, pembaca belum memiliki ketrampilan kemampuan membaca yang sesungguhnya, tetapi masih dalam tahap belajar untuk memperoleh keterampilan/kemampuan membaca. Membaca pada tingkatan ini merupakan kegiatan belajar mengenal bahasa tulis. Melalui tulisan itulah siswa dituntut dapat menyuarakan lambang-lambang bunyi bahasa tersebut.

Secara umum, pengajaran membaca permulaan dapat dilakukan dengan dua cara, yaitu induktif dan deduktif. Dalam model induktif, anak diperkenalkan unit bahasa terkecil terlebih dahulu baru kemudian mengenalkan kalimat dan wacana. Jadi, siswa diperkenalkan dulu bunyi-bunyi bahasa atau huruf huruf, baru diperkenalkan suku kata. Dari suku kata selanjutnya diperkenalkan kata dan dilanjutkan pengenalan kalimat serta teks bacaan utuh atau wacana. Metode pembelajaran membaca menulis permulaan yang menggunakan model pembelajaran induktif tersebut adalah (1) Metode Eja; (2) Metode Suku Kata; dan (3) Metode Kata Lembaga. Sedangkan pembelajaran membaca permulaan secara deduktif, anak langsung diperkenalkan dengan kalimat atau wacana terlebih dahulu, baru kemudian dikenalkan dengan kata, suku, dan huruf. Yang termasuk model pembelajaran membaca deduktif adalah (1) Metode Global dan (2) Metode Struktural Analitik dan Sintetik (SAS).

Untuk menimbulkan kegemaran anak pada dunia baca, metode pembelajaran yang digunakan di kelas awal haruslah yang menyenangkan dan mendidik. Pembelajaran membaca tidak selalu dalam bentuk menghadap sebuah buku dan anak harus berusaha dapat membaca dengan usaha yang sangat keras. Cara seperti inilah yang membuat anak tidak senang dengan pembelajaran membaca. Oleh karena itu, pembelajaran membaca permulaan harus dikemas dalam suatu model misalnya melalui permainan yang menyenangkan.

Permainan merupakan alat bagi anak untuk menjelajahi dunianya, dari yang tidak dikenali sampai pada yang diketahui, dan dari yang tidak dapat diperbuatnya sampai mampu melakukannya. Bermain bagi anak memiliki nilai dan ciri yang penting dalam kemajuan perkembangan kehidupan sehari-hari. Unsur dalam permainan antara lain pengulangan. Anak mengkonsolidasikan ketrampilannya yang harus diwujudkannya dalam berbagai 
permainan dengan nuansa yang berbeda. Dengan cara ini anak memperoleh pengalaman tambahan untuk melakukan aktivitas lain. Melalui permainan anak dapat menyatakan kebutuhannya tanpa dihukum atau terkena teguran misalnya bermain boneka diumpamakan sebagai adik yang sesungguhnya.

Salah satu metode pembelajaran yang dapat digunakan untuk pembelajaran membaca permulaan model permainan adalah metode scrambel. Pada prinsipnya metode permaianan ini menghendaki siswa untuk melakukan penyusunan atau pengurutan suatu struktur bahasa yang sebelumnya dengan sengaja telah dikacaukan. Dalam pembelajaran membaca, anak diajak untuk berlatih menyusun suatu organisasi tulisan yang sengaja dikacaukan selanjutnya anak disuruh untuk menata ulang susunan tulisan yang kacau tersebut untuk menjadi suatu tulisan yang bermakna. Hal ini anak diajak untuk lebih berkreasi dengan susunan yang baru yang mungkin akan lebih baik dari susunan yang lama. Oleh karena itu, teknik ini akan memungkinkan siswa belajar lebih santai dan tidak membuat stress, mereka akan melakukan dengan senang hati karena mereka mengira ini hanya permainan semata.

\section{Model Pembelajaran Membaca Lanjut}

Tujuan membaca lanjut adalah agar siswa dapat memahami bahasa orang lain yang tertulis serta menambah pengetahuan dan mengembangkan emosi anak. Dalam membaca lanjut dikenal metode membaca teknik, membaca dalam hati termasuk di dalamnya membaca cepat, membaca pemahaman, dan sebagainya.

Pada membaca lanjut, berdasarkan kekompleksan kognitif dalam memahami bacaan dibedakan antara membaca literal dan membaca tingkat tinggi (Burn, et.al., 1996; Syafi'ie, 1993). Pemahaman tingkat tinggi mencakup pemahaman interpretatif, pemahaman kritis, dan pemahaman kreatif. Pemahaman kritis dan kratif dapat digolongkan ke dalam pemahaman evaluatif.
Pengelompokan tingkatan membaca selengkapnya dari Burn dkk (1996):

1) Literal comprehension (pemahaman literal)

2) Interpretative coprehension (pemahaman interpretatif)

3) Critical comprehension (pemahaman kritis)

4) Creative comprehension (pemahaman kreatif).

Pemahaman literal adalah kemampuan menangkap informasi yang dinyatakan secara tersurat dalam teks. Pemahaman literal merupakan pemahaman tingkat paling rendah, tetapi jenis pemahaman ini tetap penting karena dibutuhkan dalam proses membaca secara keseluruhan. Cochran (1991:16) menjelaskan bahwa pemahaman literal mencakup rincian yang terdapat teks, rujukan kata ganti, dan urutan peristiwa dalam cerita.

Tingkat pemahaman yang kedua adalah pemahaman interpretatif, yang menurut Hafni (1981) dan Tollefson (1989) sebagai pemahaman reorganisasi dan inferensial. Pemahaman interpretatif adalah pemahaman makna antarkalimat atau makna tersirat atau penarikan kesimpulan teks. Pemahaman interpretatif merupakan proses memperoleh gagasan-gagasan yang diimplikasikan oleh teks, bukan yang bisa langsung ditemukan dalam teks. Membaca pemahaman interpretatif mencakup penarikan kesimpulan tentang gagasan utama dari suatu teks, hubungan sebab akibat yang dinyatakan secara tidak langsung dalam teks, rujukan kata ganti, rujukan kata keterangan (adverb), dan kata-kata yang dihilangkan. Pemahaman interpretatif juga mencakup pemahaman suasana hati pelaku yang terdapat dalam cerita (mood of a passage) tujuan penulis cerita tersebut, dan makna bahasa figuratif(Burn dkk., 1996).

Jenis pemahaman lebih tinggi lagi adalah pemahaman kritis/evaluatif. Pemahaman kritis/evaluatif merupakan kemampuan mengevaluasi materi teks. Pemahaman evaluatif terdapat dalam kegiatan membaca kritis. Pemahaman pembaca berada 
pada tingkat ini apabila pembaca mampu membandingkan gagasan-gagasan yang ditemukan dalam teks dengan norma-norma tertentu dan mengambil kesimpulankesimpulan yang berkaitan dengan teks. Pemahaman kritis bergantung pada pemahaman literal, pemahaman interpretatif, dan pemahaman gagasan penting yang dimplikasikan (Burn dkk., 1996).

Pemahaman kreatif merupakan tingkatan yang paling tinggi dalam membaca. Dalam proses pemahaman kreatif ini, pembaca mengembangkan pemikiran-pemikirannya sendiri untuk membentuk gagasan-gagasan baru, mengembangkan wawasan-wawasan baru, pendekatan-pendekatan baru, serta polapola pikirnya sendiri. Pembaca memanfaatkan hasil membacanya untuk mengembangkan kemampuan intelektualnya, emosionalnya, kemudian secara kreatif ia menciptakan sesuatu baik konseptual maupun praktis.

Metode pembelajaran membaca lanjut juga harus tepat. Ada beberapa metode yang biasa digunakan dalam pembelajaran membaca yang dapat dimodifikasi sesuai dengan pokok bahasan yang ada, diantaranya adalah sebagai berikut. Pertama, metode Kegiatan Membaca Langsung (KML) atau Direct Reading Activities (DRA). Penggunaan Metode KML adalah untuk mengembangkan kemampuan membaca secara komprehensif, membaca kritis, dan mengembangkan perolehan pengalaman siswa berdasarkan bentuk dan isi bacaan secara ekstensif. Kedua, metode SQ3R (Survey, Questions, Read, Recite, Review). Tujuan penggunaan metode ini untuk membentuk kebiasaan siswa berkonsentrasi dalam membaca, melatih kemampuan membaca cepat, melatih daya peramalan berkenaan dengan isi bacaan, dan mengembangkan kemampuan membaca kritis dan komprehansif. Ketiga, metode MembacaTanya Jawab (MTJ) atau Request (ReadingQuestion). Metode ini ditujukan untuk mengembangkan kemampuan membaca komprehensif, memahami alasan pengambilan kesimpulan isi bacaan, dan peramalan lanjut berkenaan dengan isi bacaan. Keempat, metode
Membaca dan Berpikir Secara Langsung (MBL) atau DRTA (Direct Reading Thinking Activities). Tujuan penggunaan metode ini, adalah untuk melatih siswa untuk berkonsentrasi dan "berpikir keras" guna memahami isi bacaan secara serius. Kelima, metode Penghubungan Pertanyaan-Jawaban (PPJ) atau QAR (Questions-Answer Relationship). Metode ini digunakan untuk mengembangkan kemampuan siswa dalam memperoleh berbagai informasi dari berbagai sumber yang berkaitan dengan berbagai bidang. Pertanyaan dapat disusun oleh guru atau dapat memanfaatkan daftar pertanyaan yang ada dalam bacaan. Keenam metode Pengelompokan dan Pemetaan Isi Bacaan/PPIB atau GMA (Group Mapping Activities). Metode ini digunakan untuk mengembangkan kemampuan siswa dalam menyusun dan memahami bagan, mengelompokkan, memetakan isi bacaan, misalnya bacaan cerita dan memetakan isi bacaan secara umum. Ketujuh metode Membaca Cepat. Dengan membaca cepat kita dapat meninjau kembali secara cepat materi yang telah dipelajari hal ini memberi kesempatan pada siswa untuk lebih luwes karena bagian yang sudah dipelajari boleh dilewati, jadi bagian-bagian yang sulit dan baru saja yang dibaca dan dipahami. Kedelapan metode membaca rumpang. Melalui metode ini pembaca diminta untuk dapat memahami wacana yang tidak lengkap (karena bagianbagian tertentu dalam wacana ini dengan sengaja dilesapkan) dengan pemahaman sempurna.

Intinya, apapun model atau metode membaca yang digunakan oleh guru di sekolah haruslah mampu memberikan motivasi pada peserta didik. Motivasi yang merupakan syarat utama agar pembelajaran menyenangkan merupakan kunci dari pembelajaran yang efektif. Gagne (dalam Bigge, 1982) menyatakan bahwa motivasi untuk pembelajaran adalah dorongan utama yang mengakibatkan seseorang dengan senang hati, terdorong untuk meraih suatu tujuan. Salah satu hambatan dalam pembelajaran adalah banyak 
siswa yang tidak tertarik pada pembelajaran membaca. Dengan adanya motivasi yang baik, siswa akan lebih mudah dan senang belajar. Motivasi dalam pembelajaran adalah usahausaha untuk menyediakan kondisi-kondisi sehingga seseorang terdorong untuk belajar lebih baik, dan mempengaruhi siswa sehingga pada diri siswa timbul dorongan untuk belajar, sehingga diperoleh pengertian, pengetahuan, sikap dan penguasaan kecakapan, agar lebih dapat mengatasi kesulitan-kesulitan.

\section{E. KESIMPULAN}

Minat baca masyarakat Indonesia termasuk siswa-siswi kita masih rendah. Penyebab rendahnya minat dan kemampuan membaca siswa antara lain karena (1) lingkungan keluarga dan sekitar yang tidak mendukung kebiasaan membaca, (2) daya beli buku masyarakat yang rendah, (3) minimnya jumlah perpustakaan yang kondisinya memadai, (4) dampak negatif perkembangan media elektronik, (5) model pembelajaran yang secara umum belum membuat siswa harus membaca, dan (6) sistem pembelajaran membaca yang belum tepat.

Solusi untuk mengatasi rendahnya minat dan kemampuan membaca antara lain (1) membiasakan anak membaca sejak dini, (2) menyediakan buku/bahan bacaan yang menarik, (3) menciptakan lingkungan yang mendukung kebiasaan membaca, (4) memperbaiki kembali penampilan perpustakaan agar menarik, (5) mengembangkan model pembelajaran membaca yang menyenangkan, bervariasi, dan mendidik Usaha-usaha ini harus ditingkatkan terus, agar kita menjadi anggota masyarakat yang literat yang terbuka cakrawala keilmuannya. Kita yang hidup di era informasi dan teknologi ini dituntut untuk selalu mengikuti perkembangan, oleh karena itu dibutuhkan aktivitas membaca yang banyak untuk menguasainya.

\section{DAFTAR PUSTAKA}

Burn, P.C., Roe, B.D., dan Ross, E.P. 1996. Teaching Reading in Today's Elementary School. Boston: Houghton Mifflin Company.

Cochran, Y. 1993. Everything You Need to Know to be a Succesfull whole Language Teacher: Plans Strategies, Technigues a More. Neshvill: Incentive Publications, Inc.

Grabe, W. \& Kaplan R. (Eds.) 1992. Introduction to Applied Linguistics. New York: Addison-Wesley Publishing Company.

Graff, Harvey J. 2006 Literacy. Microsoft ${ }^{\circledR}$ Encarta ${ }^{\circledR}$ [DVD]. Redmond, WA: MicrosoftCorporation 2005.

Hafni. 1981. Pemilihan dan Pengembangan Buku Pengajaran Membaca. Jakarta: Departemen Pendidikan dan Kebudayaan.

http://www.cybermq.com/cybermq/detail topi kutama.php?id=155\&noid=1 Minat Baca dan Pendidikan Kita, (Online)/diakses 1 Juli 2006.

Kompas.com, 29 Oktober 2009. Kemampuan Membaca Anak Indonesia Masih $\mathrm{R}$ e n d a h, ( O n 1 i n e ), http://edukasi.kompas.com/read/2009/ 10/28/21513448/Kemampuan. Membaca.Anak.Indonesia.Masih.Ren dah/diakses 5 Januari 2010.

Tollefson, J.W. 1989. A System for Improving Teachers Question. Forum. 27 (1): 6 9.

Syafi'ie, Imam. 1999. Pengajaran Membaca Kelas-kelas Awal Sekolah Dasar. Pidato Pengukuhan Guru Besar dalam Bidang Ilmu Pengajaran Bahasa Indonesia pada Fakultas Pendidikan Bahasa dan Seni Universitas Negeri Malang tanggal 7 Desember. 